\title{
Influence of premature loss of the first permanent molar on the dental arches morphology - radiological evaluation
}

\author{
Influenţa pierderii premature a primului molar permanent asupra \\ morfologiei arcadelor dentare - evaluare radiologică
}

\author{
Andreea Pop ${ }^{1}$, Radu Septimiu Câmpian' ${ }^{1}$, Mariana Păcurar ${ }^{2}$, Ecaterina Ionescư ${ }^{3}$, \\ Elina Teodorescu ${ }^{4}$, Ştefan Milicescu ${ }^{4}$, Paula Jiman ${ }^{5}$, Olimpia Bunta ${ }^{6}$, Viorica Țărmure ${ }^{6}$ \\ ${ }^{1}$ Disciplina Reabilitare Orală, Sănătate şi Management, \\ Universitatea de Medicină şi Farmacie „Iuliu Haţieganu“, Cluj-Napoca, România \\ ${ }^{2}$ Disciplina Ortodonţie, Universitatea de Medicină şi Farmacie, Târgu-Mureş, România \\ ${ }^{3}$ Disciplina Ortodonţie, Universitatea de Medicină şi Farmacie „Carol Davila“, Bucureşti, România \\ ${ }^{4}$ Disciplina Protetică Dentară, Universitatea de Medicină şi Farmacie „Carol Davila“, Bucureşti, România \\ 5Universitatea de Medicină şi Farmacie „Iuliu Haţieganu“, Cluj-Napoca, România \\ ${ }^{6}$ Disciplina Ortodonţie, Universitatea de Medicină şi Farmacie „Iuliu Haţieganu“, Cluj-Napoca, România
}

\begin{abstract}
Objectives. The purpose of this research was to radiological identify the morphological changes of the dental arcades resulting from the premature loss of the permanent first molars.

Material and method. The study was conducted between 2014-2016 on a group of 50 patients aged $12-15$ years who presented themselves with the imminence of premature loss of the first permanent molars. 1: 1 panoramic radiographies were performed before the extractions and at 6 and 12 months after the extractions respectively. Results and discussions. The changes in position of the antagonist teeth and those of the second permanent molars, in the two dental arches, both in the sagittal and in the vertical plane were revealed.

Conclusions. The premature loss of the first permanent molars, especially after the eruption of the second permanent molars, causes unwanted dental movements and severe dental-maxillary abnormalities over time.
\end{abstract}

Keywords: first permanent molar, premature extraction, tooth position changes, dental-maxillary abnormalities

\section{REZUMAT}

Obiective. Prezenta cercetare işi propune identificarea radiologică a modificărilor morfologice ale arcadelor dentare apărute în urma pierderii premature a molarilor primi permanenţi.

Material şi metodă. Studiul a fost realizat între anii 2014 şi 2016, asupra unui lot de 50 de pacienţi cu vârste cuprinse în intervalul 12-15 ani, care s-au prezentat cu iminenţa pierderii premature a primilor molari permanenţi. S-au realizat radiografii panoramice în raport 1:1, înainte de efectuarea extracţiilor şi la 6 , respectiv 12 luni după efectuarea acestora.

Rezultate şi discuţii. S-au evidenţiat modificările de poziţie ale dinţilor antagonişti cât şi cele ale molarilor doi permanenţi, în ambele arcade, atât în plan sagital, cât şi în plan vertical.

Concluzii. Pierderea prematură a primilor molari permanenţi, în mod deosebit după erupţia molarilor doi permanenţi, determină deplasări dentare nedorite şi severe anomalii dento-maxilare în timp.

Cuvinte cheie: molar prim permanent, extracţie prematură, modificări de poziţie unidentare, anomalii dento-maxilare 


\section{INTRODUCERE}

Primul molar permanent este, fără îndoială, una dintre cele mai importante unităţi masticatorii din cavitatea bucală şi este esenţial pentru dezvoltarea unei ocluzii funcționale. A fost citat ca fiind cel mai predispus dinte permanent la carii, probabil ca rezultat al expunerii sale precoce la mediul oral. Pierderea precoce a unui molar prim permanent la un copil duce la schimbări morfologice însemnate ale arcadelor dentare, cu afectarea ocluziei statice şi a celei dinamice. Lipsa măsurilor de prevenire a acestui fenomen, cât şi lipsa unui tratament interceptiv precoce poate conduce la afectări, mai mult sau mai puțin severe, ale articulației temporo-mandibulare, cu simptomatologie caracteristică (1).

Deoarece ocluzia prezintă o evoluție constantă pe parcursul celor trei dentații (dentația temporară, mixtă şi permanentă), pierderea prematură a molarului prim permanent induce modificări de poziție ale dinților vecini, ale dinților antagonişti, cât şi fenomene tip domino la nivelul ocluziei, determinând apariţia unui tablou clinic variat de anomalii dentomaxilare (2).

Există numeroşi factori care ar trebui luaţi în considerare în planificarea tratamentului cariilor complicate ale molarilor prim permanenți. În eventualitatea diagnosticului de rest radicular sau distrucție coronară masivă, cu sau fără procese periapicale acute/cronice, se poate considera că „,momentul ideal" pentru pierderea acestui dinte este la începutul fenomenului de calcificare a bifurcației molarilor doi permanenți, care apare de obicei la o vârstă cronologică de la opt până la zece ani $(3,5)$.

Este frecvent citat faptul că primul molar permanent nu este dintele ideal pentru a fi extras în scop ortodontic, deoarece spațiul astfel „câştigat” este de obicei prea mare şi localizat în zonele pos-

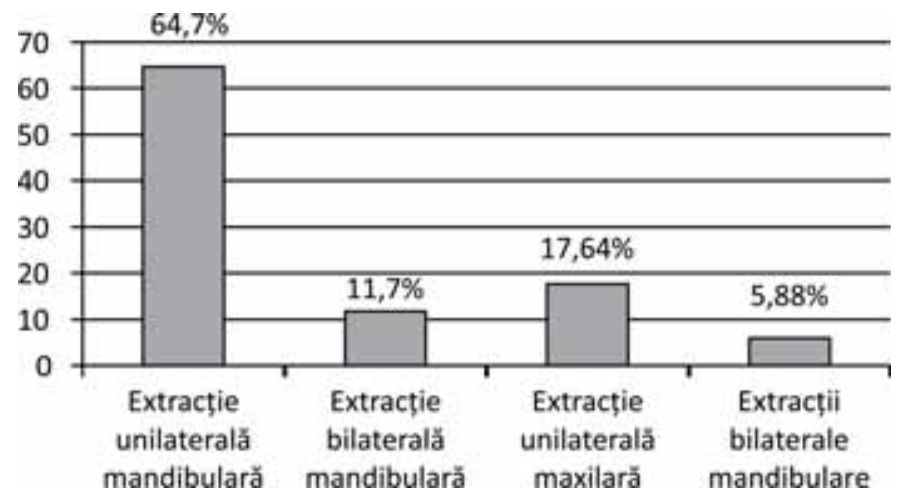

terioare ale arcadelor dentare, la mare distanță de focarele de înghesuire. Totuşi, extracția de prim molar permanent cu prognostic scăzut a fost recomandată în literatura ortodontică (1-3).

\section{MATERIAL ŞI METODĂ}

Am realizat un studiu longitudinal, între anii 2014 şi 2016, asupra unui lot de 50 de pacienți cu vârste cuprinse în intervalul 12-15 ani, care s-au prezentat la Disciplina de Ortodonție din cadrul Universităţii de Medicină şi Farmacie „Iuliu Haţieganu" Cluj-Napoca, Romania, cu iminența pierderii premature a primilor molari permanenți. S-au realizat radiografii panoramice în raport 1:1, înainte de efectuarea extracțiilor şi la 6 , respectiv 12 luni după efectuarea acestora.

Selecția pacienților s-a realizat pe criterii de vârstă şi status odontal al molarilor primi permanenți - carii complicate şi/sau distrucții coronare masive la cel puțin unul dintre cei patru dinţi de acest fel, cât şi prezența examinării complementare de tip ortopantomografie la momentul prezentării pacienților la tratament şi după realizarea extracțiilor dentare.

\section{REZULTATE ŞI DISCUŢII}

Din totalul cazurilor examinate, se constată frecvența ridicată a extracției unilaterale de molar prim permanent mandibular, comparativ cu situația extracţiei unilaterale a aceluiaşi dinte la nivel maxilar sau a extracțiilor simetrice maxilare sau mandibulare.

Analizând situația extracțiilor premature de molar prim permanent, pe grupe de vârstă, la lotul de pacienți analizat, se constată că, în jurul vârstei de 14 ani, frecvența acestor extracții este mai mare.
FIGURA 1. Situația extracțiilor premature a primului molar permanent în funcție de localizare şi numărul dinților extraşi 


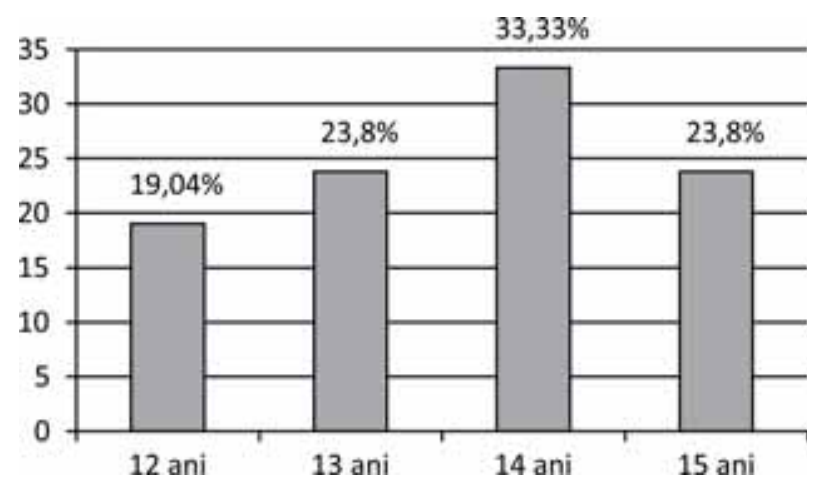

FIGURA 2. Situația extracțiilor premature a primului molar permanent în functie de vârstă

În ceea ce priveşte modificările de poziție unidentare ale molarului doi permanent, am constatat modificări ale acestuia atât în sens sagital, cât şi în sens vertical. Astfel, în sens sagital: 95,23\% dintre cazuri au prezentat modificări de pozitțe unidentare ale molarului doi permanent erupt pe arcadă. În $66,66 \%$ dintre cazuri, M2 au prezentat o mezioversiune în intervalul 6-12 luni postextracțional, dintre care $28,57 \%$ localizate în arcada superioară, iar $71,42 \%$ localizate în arcada inferioară. În 14,28\% dintre cazuri, M2 au prezentat o mezio-versiune în intervalul 0-6 luni postextracțional, dintre care $66,66 \%$ au fost localizate în arcada superioară, iar $33,33 \%$ în arcada inferioară. Pentru cazurile în care M2 nu era erupt pe arcadă la momentul extracției premature a molarului prim permanent, s-a constatat o mezio-gresiune a M2 în 14,28\% dintre cazuri, evident în mod deosebit în intervalul 6-12 postextracțional, în special în arcada inferioară.

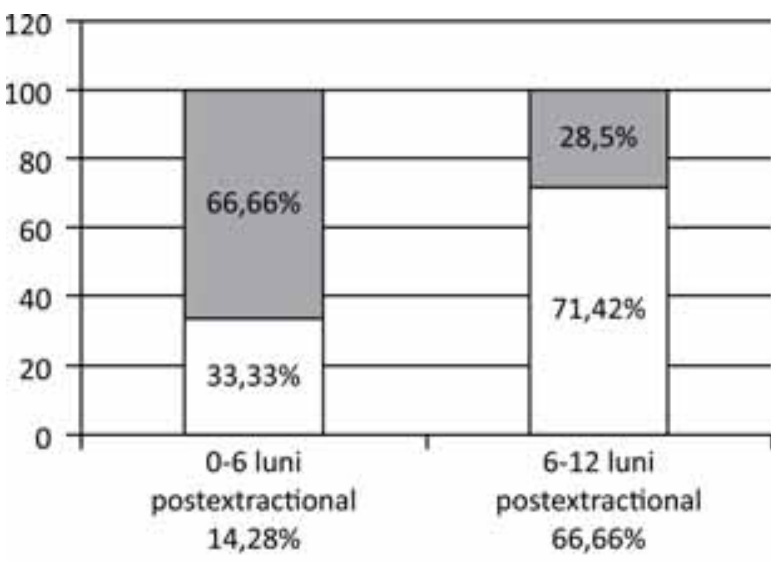

口Mezioversiune M2 inferior

DMezioversiune M2 superior

FIGURA 3. Modificările de poziție în sens sagital ale molarului doi permanent
În sens vertical, $47,61 \%$ dintre cazurile analizate au prezentat modificări de poziție unidentare ale molarului doi permanent la sfârşitul intervalului 6-12 luni postextracțional. Egresiunea dinților antagonişti în intervalul 0-6 luni postextracțional a fost prezentă la 4,76\% dintre cazuri (dintre aceştia, $100 \%$ în arcada superioară, $0 \%$ în arcada mandibulară). $28,57 \%$ dintre cazuri au prezentat egresiunea dinţilor antagonişti în intervalul 6-12 luni postextracțional (dintre aceştia, 16,66\% in arcada superioară, iar 83,33\% în arcada inferioară). Extruzia antagoniştilor a fost prezentă la 4,76\% dintre cazuri în intervalul 0-6 luni postextracţional şi la 9,52\% dintre cazuri în intervalul 6-12 luni postextracțional.

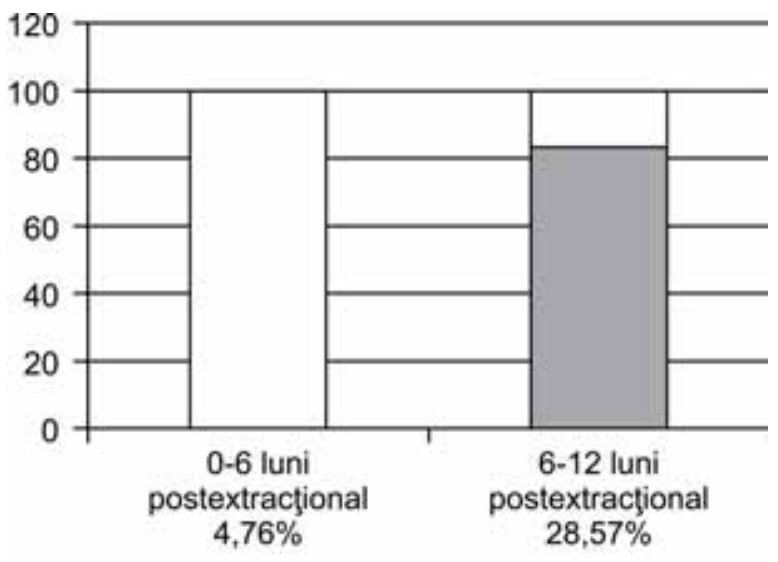

\section{$\square$ Egresiune antagonişti superiori}

$\square$ Egresiune antagonişti inferiori

FIGURA 4. Modificări în sens vertical ale dinților antagonişti - egresiune

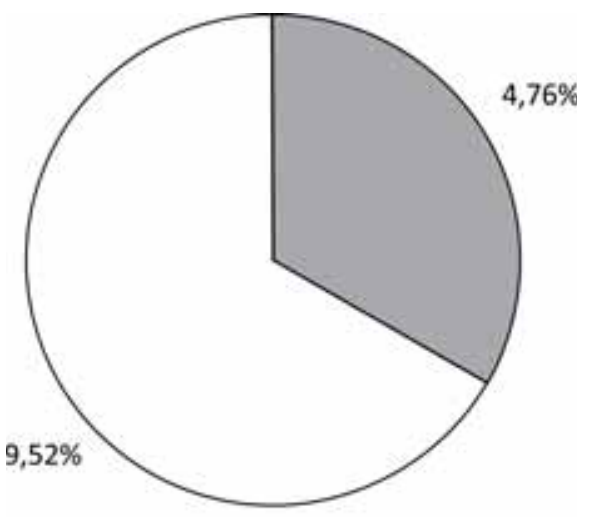

$\square$ Extruzie antagonişti 0-6 luni postextracțional

口Extruzie antagonişti 6-12 luni postextracţional

Figura 5. Modificări în sens vertical ale dinților antagonişti - extruzie

\section{CONCLUZII}

Pierderea prematură a primilor molari permanenți, în mod deosebit după erupția molarilor doi 
permanenți, determină deplasări dentare nedorite şi severe anomalii dento-maxilare în timp. Prevenția cariei sau tratamentul conservativ realizat în faze incipiente ale cariei dentare ar conduce la prevenirea anomaliilor dento-maxilare, cât şi a patologiilor articulației temporo-mandibulare pe care pierderile

\section{BIBLIOGRAFIE}

1. Gill D.S., Lee R.T., Tredwin C.J. Treatment Planning for the Loss of First Permanent Molars. Dent Update. 2001; 28(6)304-8.

2. Rajashekhara B.S., Keyur J.M., Bhavna D. et al. Management of early loss of first permanent molar: A new technique. J Indian Soc Pedod Prev Dent. 2012; 30:349-51.

3. Albadri S., Zaitoun H., McDonnell S.T. et al. Extraction of first permanent molar teeth: results from three dental hospitals. British Dental Journal. 2007; 203:E14.

4. Sandler P.J., Atkinson R., Murray A.M. For four sixes. Am J Orthod Dentofacial Orthop 2000; 117:418-34.

5. Patel S., Ashley P., Noar J. Radiographic prognostic factors determining spontaneous space closure after loss of premature a dinților permanenți le determină în timp. În eventualitatea iminenței pierderii molarului prim permanent, se recomandă tratament ortodontic imediat, adaptat vârstei pacientului, în vederea prevenirii apariţiei anomaliilor dento-maxilare conexe.

Conflict of interest: none declared Financial support: none declared

the permanent first molar. Am J Orthod Dentofacial Orthop. 2017; 151(4):718-26.

6. Jälevik B., Möller M. Evaluation of spontaneous space closure and development of permanent dentition after extraction of hypomineralized permanent first molars. Int $\mathrm{J}$ Paediatr Dent. 2007; 17:328-35.

7. Cernei E.R., Mavru R.B., Zetui I.N. Second molar uprighting after premature loss of mandibular first permanent molarcase report. Rev Med Chir Soc Med Nat lasi. 2015; 119(2):572-8. 